\section{Check for updates}

Cite this: J. Mater. Chem. A, 2021, 9 , 14775

Received 28th March 2021 Accepted 6th June 2021

DOI: $10.1039 / d 1 \operatorname{ta0} 2555 d$

rsc.li/materials-a

\title{
Effects of $\mathrm{NiO}$ addition on sintering and proton uptake of $\mathrm{Ba}(\mathrm{Zr}, \mathrm{Ce}, \mathrm{Y}) \mathrm{O}_{3-\delta^{\dagger}} \dagger$
}

\begin{abstract}
Yuanye Huang, $\mathbb{D} \ddagger$ Rotraut Merkle $\mathbb{D}$ * and Joachim Maier
The effects of $0.125-2.0 \mathrm{wt} \% \mathrm{NiO}$ added as a sintering aid for highly refractory $\mathrm{Ba}(\mathrm{Zr}, \mathrm{Ce}, \mathrm{Y}) \mathrm{O}_{3-\delta}$ proton conducting ceramics are investigated. The complex nature of the solid state reactive sintering method shows up in the phase evolution (quenched samples exhibit up to three different perovskite phases) and the densification kinetics. For $\geq$ $0.25 \mathrm{wt} \% \mathrm{NiO}$ addition the characteristic changes in the sintering behavior indicate that a $(\mathrm{Ba}, \mathrm{Ni}, \mathrm{Y}) \mathrm{O}_{x}$ transient liquid phase forms which simultaneously facilitates densification, grain growth, and homogeneous $(\mathrm{Zr}, \mathrm{Ce}, \mathrm{Y})$ cation distribution (indicated by decreased microstrain). However, thermogravimetry shows a clear decrease of proton uptake and effective acceptor concentration with increasing amounts of $\mathrm{NiO}$. This can be attributed to a withdrawal of $\mathrm{Ba}$ from the perovskite lattice, which decreases the effective acceptor concentration. A NiO content of $0.4-0.5 \mathrm{wt} \%$ is suggested as a balance between the benefits for phase formation and sintering, and its drawback for proton uptake.
\end{abstract}

\section{Introduction}

Fuel cells based on ceramic proton conducting electrolytes (protonic ceramic fuel cells, PCFCs) have several advantages over oxide conductor based solid oxide fuel cells (SOFCs) such as a higher electrolyte conductivity at intermediate temperatures $\left(300-600{ }^{\circ} \mathrm{C}\right)$, and water formation at the cathode side which facilitates operation at high fuel utilization (see e.g. ref. 1-7). In addition, operation in electrolysis mode (directly producing dry compressed hydrogen) or catalytic membrane reactors becomes increasingly attractive. ${ }^{8-11}$ The basis for these applications is the availability of proton-conducting electrolytes in the form of planar or tubular membranes. Y-doped $\mathrm{BaZrO}_{3}$ (BZY) combines a high bulk proton conductivity with good chemical stability. ${ }^{2,12}$ However, its poor sinterability and blocking nature of the grain boundaries (GBs) have severely impeded its application (see e.g. ref. 12-15). Partial substitution of $\mathrm{Zr}$ by Ce improves both aspects, but too high ceria contents are detrimental for chemical stability against $\mathrm{CO}_{2}$ and $\mathrm{H}_{2} \mathrm{O}^{12,16,17}$ The use of $\mathrm{NiO}$ as a sintering aid in a solid state reactive sintering approach (SSRS ${ }^{18-22}$ ) allows for improved densification and grain growth at decreased temperature (typically $1400-1550{ }^{\circ} \mathrm{C}$ ) via formation of a transient $(\mathrm{Ba}, \mathrm{Ni}, \mathrm{Y}) \mathrm{O}_{x}$ liquid phase. SSRS has been successfully applied for PCFCs (see e.g. ref. 5) and tubular reactors. ${ }^{10,11}$

Max Planck Institute for Solid State Research, Heisenbergstraße 1, Stuttgart, 70569, Germany. E-mail: r.merkle@fkf.mpg.de

$\dagger$ Electronic supplementary information (ESI) available. See DOI: $10.1039 / \mathrm{d} 1 \mathrm{ta0} 2555 \mathrm{~d}$

\$ Present address: Empa, Swiss Federal Laboratories for Materials Science and Technology, Überlandstraße 129, 8600, Dübendorf, Switzerland.
While other additives such as $\mathrm{ZnO},{ }^{19,23} \mathrm{CoO},{ }^{19,24}$ and $\mathrm{CuO}^{19,25}$ also improve the sintering, $\mathrm{NiO}$ is preferred because it is present in PCFCs on the anode side anyway and - if not deliberately added to the electrolyte layer - diffuses in from the anode BZY-Ni mixture. ${ }^{7,26,27}$ Although SSRS with NiO tends to yield better bulk and grain boundary conductivities than the use of other sintering aids and procedures, $\mathrm{NiO}$ addition has also detrimental effects (see e.g. ref. 20, 21, 26 and 28-31). They are related to Ni-rich residues of the transient liquid phase which, in particular for high $\mathrm{NiO}$ addition, may lead to cracking and potentially even electronic short-circuits when the material is exposed to reducing conditions. In addition, the liquid phase formation may affect the cation composition of the grain interior, and thus proton uptake as well as bulk and GB conductivity. Specific temperature treatments have been suggested (see e.g. ref. 21, 28 and 29) to decrease these problems. It is obvious that a balance between improved sintering and decreased bulk conductivity must be found.

For this purpose, in the present work the effect of different amounts of NiO addition to $\mathrm{Ba}_{1.015} \mathrm{Zr}_{0.664} \mathrm{Ce}_{0.20} \mathrm{Y}_{0.136} \mathrm{O}_{3-\delta}$ and $\mathrm{Ba}_{1.015} \mathrm{Zr}_{0.63} \mathrm{Ce}_{0.20} \mathrm{Y}_{0.17} \mathrm{O}_{3-\delta}$ are investigated with respect to the sintering properties (densification and grain size as function of time and temperature) and bulk proton uptake (from which the effective acceptor concentration can be derived). Limiting the Ce substitution to $20 \mathrm{~mol} \%$ keeps the material safely in the stability range versus $\mathrm{CO}_{2}$ and $\mathrm{H}_{2} \mathrm{O}$, and a slight nominal $\mathrm{Ba}$ excess is used to compensate for potential $\mathrm{BaO}$ loss in the sintering. $1.0 \mathrm{wt} \% \mathrm{NiO}$ is frequently used in literature, ${ }^{18-21}$ but occasionally also $0.5 \mathrm{wt} \%$ (ref. 32 and 33 ) and $2.0 \mathrm{wt} \%$ (ref. 18, 20 and 34 ) have been tested. The NiO addition is varied from $0.125 \mathrm{wt} \%$ to $1.0 \mathrm{wt} \%$ to identify the optimum NiO content, and $2.0 \mathrm{wt} \% \mathrm{NiO}$ addition is used for investigating the liquid phase sintering mechanisms. A 
detailed investigation of bulk and GB conductivity will be reported separately.

\section{Experimental}

\subsection{Sample preparation}

$\mathrm{Ba}(\mathrm{Zr}, \mathrm{Ce}, \mathrm{Y}) \mathrm{O}_{3-\delta}$ (BZCY) samples were prepared by the SSRS method, in which $\mathrm{NiO}$ is added in excess to the $\mathrm{Ba}(\mathrm{Zr}, \mathrm{Ce}, \mathrm{Y}) \mathrm{O}_{3-\delta}$ cation stoichiometry. The nominal cation ratios of $\mathrm{Ba}: \mathrm{Zr}: \mathrm{Ce}: \mathrm{Y}$ in the present work are $1.015: 0.664: 0.20: 0.136$ and $1.015: 0.63: 0.20: 0.17$. The respective amounts of $\mathrm{BaCO}_{3}$ (Alfa Aesar, 99.8\%), $\mathrm{CeO}_{2}$ (Sigma Aldrich, 99.8\%), $\mathrm{ZrO}_{2}$ (Tosoh TZ-0), $\mathrm{Y}_{2} \mathrm{O}_{3}$ (Alfa Aesar, 99.9\%) and 0.125-2.0 wt\% NiO (Alfa Aesar, 99\%) were wet milled in isopropanol in a zirconia vessel with zirconia balls for $24 \mathrm{~h}$ (Fritsch Pulverisette 5). After drying, the powder was dry-ball-milled for $1 \mathrm{~h}$ (Friatec vibrating mill with a single large zirconia ball) to break agglomerates. SEM images of the powder showed a particle size about $0.5 \mu \mathrm{m}$ after ball milling. According to XRD the milled powder still consisted of the initial phases (Fig. S4 $\dagger$ ), i.e., no mechanochemical reaction had occurred.

Isostatically pressed (200 MPa) green pellets of about $10 \mathrm{~mm}$ diameter and $5 \mathrm{~mm}$ thickness were embedded in sacrificial powder $\left(\mathrm{BaZrO}_{3}\right.$ (Sigma Aldrich) with $\left.10 \mathrm{wt} \% \mathrm{BaCO}_{3}\right)$. The samples were sintered in Y-stabilized zirconia crucibles at 1450$1550{ }^{\circ} \mathrm{C}$ with a heating and cooling rate of $200 \mathrm{~K} \mathrm{~h}^{-1}$ and soaking time of 1-16 h; some experiments ("fast sintering") were carried out with a faster nominal heating and cooling rate of $600 \mathrm{~K} \mathrm{~h}^{-1}$ and shorter soaking time of 0.25 or $1 \mathrm{~h}$. For quenching experiments, the samples were heated to the desired temperature with a rate of $600 \mathrm{~K} \mathrm{~h}^{-1}$, and after 10 min soaking time the crucible was vertically dragged out from the oven by an attached Pt wire.

SSRS of $\mathrm{Ba}_{1.015} \mathrm{Zr}_{0.63} \mathrm{Ce}_{0.20} \mathrm{Y}_{0.17} \mathrm{O}_{3-\delta}$ with different NiO addition was also investigated. It shows the same tendency as $\mathrm{Ba}_{1.015} \mathrm{Zr}_{0.664} \mathrm{Ce}_{0.20} \mathrm{Y}_{0.136} \mathrm{O}_{3-\delta}$, as shown in Fig. S3. $\dagger$ Therefore, the discussion will focus on $\mathrm{Ba}_{1.015} \mathrm{Zr}_{0.664} \mathrm{Ce}_{0.20} \mathrm{Y}_{0.136} \mathrm{O}_{3-\delta}$ unless stated differently.

For comparison, some samples were sintered by spark plasma sintering (SPS). For these samples, powders having the perovskite structure were prepared by conventional solid state reaction from $\mathrm{BaCO}_{3}, \mathrm{CeO}_{2}, \mathrm{ZrO}_{2}-\mathrm{Y}_{2} \mathrm{O}_{3}$ (Tosoh TZ-10) without/ with $\mathrm{NiO}$ by repeated dry ball milling and calcination $(4 \mathrm{~h}$ at $1100{ }^{\circ} \mathrm{C}$, followed by three times $8 \mathrm{~h}$ at $1300{ }^{\circ} \mathrm{C}$ ). Densification by SPS (FCT Systeme, Frankenblick, Germany) was performed in graphite dies $(\phi=20 \mathrm{~mm})$ with a uniaxial pressure of $0.4 \mathrm{kbar}$ and holding time of $5 \mathrm{~min}$ at $1450{ }^{\circ} \mathrm{C}$ (Ni-free BZCY), $1350{ }^{\circ} \mathrm{C}$ (1.0 at\% Ni at B-site) and $1300{ }^{\circ} \mathrm{C}$ (4.0 at\% Ni at B-site). These samples were post-annealed in Y-stabilized zirconia crucibles buried in sacrificial powder $\left(\mathrm{BaZrO}_{3}\right.$ with $\left.10 \mathrm{wt} \% \mathrm{BaCO}_{3}\right)$ for $4 \mathrm{~h}$ at $1500{ }^{\circ} \mathrm{C}$ (Ni-free), $1400{ }^{\circ} \mathrm{C}$ (Ni-containing), with a heating and cooling rate of $200 \mathrm{~K} \mathrm{~h}^{-1}$.

\subsection{Characterization}

The density of samples was calculated from weight and geometry, the theoretical density was calculated from X-ray diffraction (XRD) lattice constants and nominal composition. $\mathrm{XRD}$ was performed using $\mathrm{Cu} \mathrm{K} \alpha$ radiation in Bragg-Brentano geometry (Panalytical Empyrean) on the sintered samples after manually grinding off the surface layer.

To check the chemical composition, about $50 \mathrm{mg}$ of ground powder from the sintered sample was dissolved into $3.0 \mathrm{vol} \%$ $\mathrm{HCl}$ solution in a microwave autoclave, and measured by inductively coupled plasma-optical emission spectrometry (ICPOES, Spectro Ciros). The ICP-OES results are shown and discussed in Tables S1, S2 and Fig. S1. $\dagger$

Scanning electron microscopy (SEM, ZEISS Merlin) was used to determine the mean grain size by the linear intercept method and the grain size distribution from the top-view images of the etched surface. The samples were chemically etched in $10 \mathrm{vol} \%$ aqueous $\mathrm{HCl}$ for $20 \mathrm{~min}$. Some samples were thermally etched for $1 \mathrm{~h}$ at $50 \mathrm{~K}$ below their sintering temperature (or the annealing temperature for SPS samples) for better image quality.

The proton uptake was measured by thermogravimetry (TG, Netzsch STA 449) on sintered pellets crushed and sieved to a particle size $\leq 300 \mu \mathrm{m}$ (typical sample weight $c a .500 \mathrm{mg}$ ). The samples were first heated in dry $\mathrm{N}_{2}\left(60 \mathrm{ml} \mathrm{min}^{-1}\right)$ to $900{ }^{\circ} \mathrm{C}$, then the atmosphere was switched to 17 mbar $\mathrm{H}_{2} \mathrm{O}$ in $\mathrm{N}_{2}$, the respective weight change yields the absolute water content at $900{ }^{\circ} \mathrm{C}$. The samples were cooled with rates of $1 \mathrm{~K} \mathrm{~min}^{-1}$ down to $600{ }^{\circ} \mathrm{C}, 0.6 \mathrm{~K} \mathrm{~min}^{-1}$ down to $400{ }^{\circ} \mathrm{C}, 0.3 \mathrm{~K} \mathrm{~min}^{-1}$ down to $300{ }^{\circ} \mathrm{C}$. For selected samples the reversibility was checked by heating again with the respective rate; the absence of hysteresis indicated that the hydration reaction had reached equilibrium. Buoyancy correction was performed using data recorded for an empty crucible.

Local element distribution and images of the quenched samples were investigated by transmission electron microscopy (TEM, ARM200CF TEM, JEOL, USA) equipped with electron energy loss spectroscopy (TEM-EELS). The instrument integrates spherical $\left(C_{\mathrm{s}}\right)$ aberrations of the condenser lenses and provides atomic resolution. TEM samples were mechanically ground and polished by MultiPrep wedge polisher (Allied High Tech Products, Inc., USA), after which a final ion-beam milling with low energy Ar ions (1 keV) was applied in a PIPS1 (Gatan, Inc., USA) at room temperature. Bright-field (BF) images were obtained with a resolution of $0.2 \mathrm{~nm}$ and high-angle annular dark-field (HAADF) with a resolution $<0.1 \mathrm{~nm}$ (electron scattered to angles 0-111 mrad).

\section{Results and discussion}

\subsection{Sintering behavior}

Acceptor-doped $\mathrm{BaZrO}_{3}$ materials are known to require drastic sintering conditions. Conventional sintering at $1500{ }^{\circ} \mathrm{C}$ without $\mathrm{NiO}$ addition yields low densities, ${ }^{20}$ a temperature of $1600{ }^{\circ} \mathrm{C}$ yields dense samples but the grain size remains $\leq 1 \mu \mathrm{m}$ (ref. 35 ) despite a long soaking time of $24 \mathrm{~h}$. In the SPS process for $\mathrm{Ni}$ free samples, uniaxial pressure is applied at a temperature where plastic deformation of the grains becomes possible. This results in a high density of $\geq 95 \%$, but the grain size remains close to that in the starting powder at about $0.5 \mu \mathrm{m}$ (Fig. 1a). 

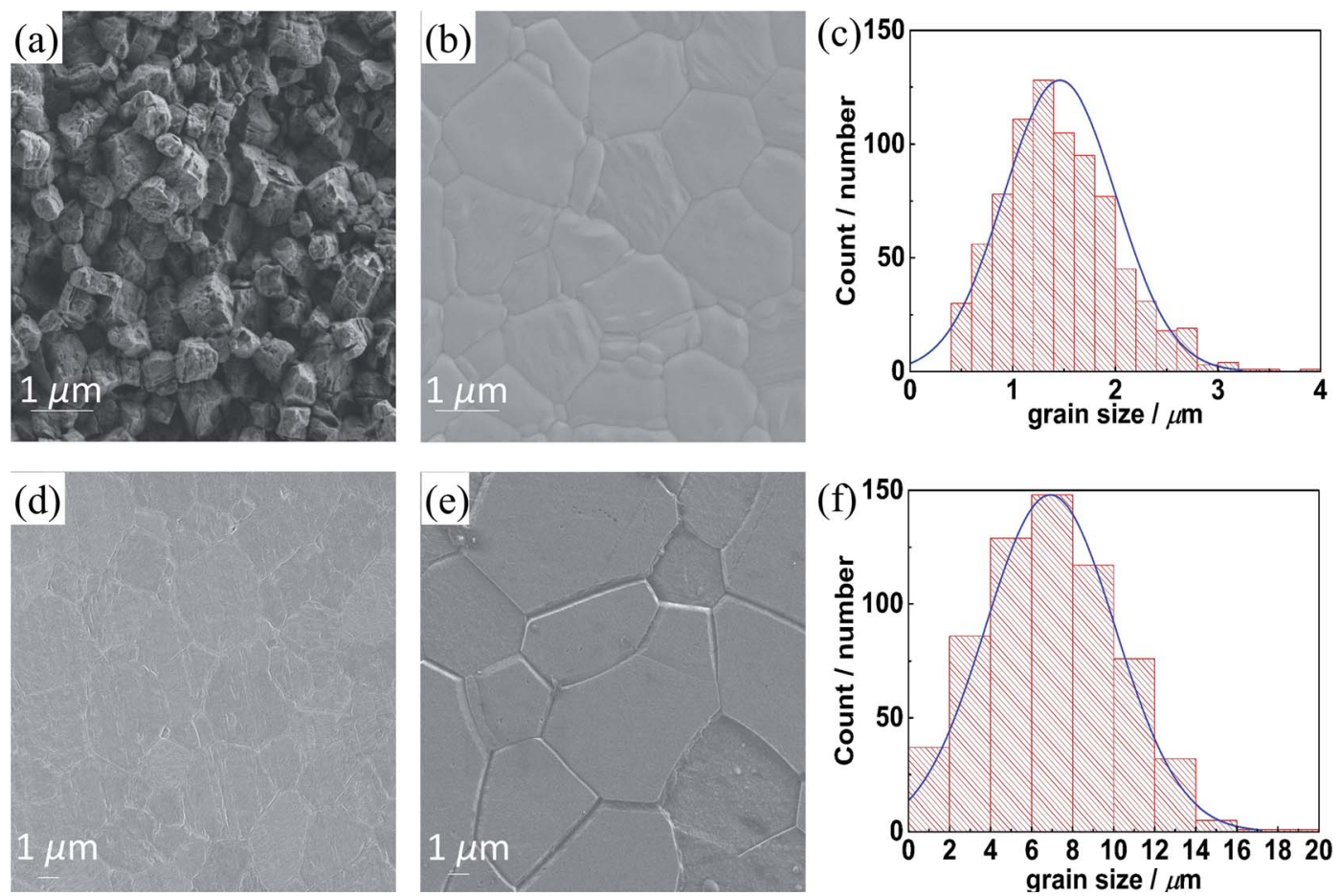

Fig. 1 SEM images for $\mathrm{Ba}_{1.015} \mathrm{Zr}_{0.664} \mathrm{Ce}_{0.20} \mathrm{Y}_{0.136} \mathrm{O}_{3-\delta}$. (a) SPS sample without $\mathrm{Ni}\left(5 \mathrm{~min} 1450{ }^{\circ} \mathrm{C}+\right.$ post-annealing $4 \mathrm{~h}$ at $1500{ }^{\circ} \mathrm{C}$ ). (b, d and e) SSRS samples sintered for $16 \mathrm{~h}$ at $1550{ }^{\circ} \mathrm{C}$ with (b) $0.25 \mathrm{wt} \% \mathrm{NiO}$; (d) $0.5 \mathrm{wt} \% \mathrm{NiO}$ and (e) $1.0 \mathrm{wt} \% \mathrm{NiO}$. (c and f) Grain size distribution for the SSRS samples with 0.25 and 1.0 wt $\%$ NiO.

Even extended annealing of SPS samples at $1700^{\circ} \mathrm{C}$ for $20 \mathrm{~h}$ does not lead to perceptible grain growth. ${ }^{36}$

Depending on the added NiO amount, the situation differs strongly for the SSRS process. It is important to recognize that an addition of $1.0 \mathrm{wt} \% \mathrm{NiO}$ corresponds to $\approx 4.0$ at $\% \mathrm{Ni}$ (relative to the B-site cations), which yields about $3-6 \mathrm{vol} \%$ of a transient liquid phase (assuming the melt consists of $\mathrm{BaNiO}_{2}$ or $\mathrm{BaY}_{2} \mathrm{NiO}_{5}$, see discussion below and in ref. 37). The beneficial effect of SSRS with NiO addition is illustrated in Fig. 1. For the SSRS sample with $0.25 \mathrm{wt} \% \mathrm{NiO}$, the grain size remains small $\approx 1 \mu \mathrm{m}$ (this agrees with the results in ref. 38 for $0.2 \mathrm{wt} \% \mathrm{NiO}$ ). When a higher amount of 0.5 or $1.0 \mathrm{wt} \% \mathrm{NiO}$ is used, the grains grow up to $2-6 \mu \mathrm{m}$. For the latter sample the grains actually develop the equilibrium hexagonal shape predicted by the Wulff construction. These results clearly demonstrate the effect of $\mathrm{NiO}$ addition in promoting BZCY grain growth and densification. While the average grain size of the sample with $1.0 \mathrm{wt} \%$ $\mathrm{NiO}$ addition is much larger than the one with $0.25 \mathrm{wt} \% \mathrm{NiO}$, the shape and width of the grain size distribution is similar (the average grain sizes from Fig. $1 \mathrm{c}$ and $\mathrm{f}$ are larger than those from intercept linear method because the size distribution was calculated from individual grain whose size was measured by the longest diagonal).

The relative density and grain size of samples with different $\mathrm{NiO}$ content are plotted in Fig. 2. For $0.25 \mathrm{wt} \% \mathrm{NiO}$ or less, high sintering temperatures and long soaking times are required for full densification, but the grains remain small $(\approx 1 \mu \mathrm{m})$. Fig. S2a $\dagger$ demonstrates similar behavior for $0.125 \mathrm{wt} \%$. However, for $\geq 0.375 \mathrm{wt} \% \mathrm{NiO}$ (Fig. $2 \mathrm{~b}-\mathrm{f}, \mathrm{S} 2 \mathrm{~b}$ and d $\dagger$ ), already lower sintering temperature and shorter soaking time results in densities $\geq 95 \%$ (similar to the trend for Ce-rich $\mathrm{BaZr}_{0.1} \mathrm{Ce}_{0.7^{-}}$ $\mathrm{Y}_{0.2} \mathrm{O}_{3-\delta}$ (ref. 33)). In parallel to the densification the grains grow significantly. To access shorter soaking time, the heating and cooling rate was increased to $600 \mathrm{~K} \mathrm{~h}^{-1}$ for $0.5-1.0 \mathrm{wt} \% \mathrm{NiO}$ (blue dots in Fig. 2). These data demonstrate that a high NiO content of $1.0 \mathrm{wt} \%$ yields a high density already at $1400{ }^{\circ} \mathrm{C}$. These results show that dense samples can be obtained above $1400-1450{ }^{\circ} \mathrm{C}$ for $1.0-0.5 \mathrm{wt} \% \mathrm{NiO}$ addition. However, in order to achieve pronounced grain growth (decreasing the number of low-conductive GBs), $1500-1550^{\circ} \mathrm{C}$ and extended soaking times are necessary. The lattice parameters of the SSRS samples show no systematic dependence on the sintering conditions but a characteristic variation with NiO content, as discussed in Section 3.3.

Fig. 3 gives further insight into the dependence of the SSRS sintering process on the NiO content. When $\leq 0.25 \mathrm{wt} \% \mathrm{NiO}$ is used, the densification process largely occurs without pronounced grain growth, the grain size remains below $1 \mu \mathrm{m}$ (Fig. 3a). On the other hand, higher NiO contents $\geq 0.375 \mathrm{wt} \%$ $\mathrm{NiO}$ lead to grain growth in parallel to the densification. The maximum grain size that is achieved for $16 \mathrm{~h}$ at $1550{ }^{\circ} \mathrm{C}$ then increases with $\mathrm{NiO}$ addition, and exceeds $5 \mu \mathrm{m}$ for $1.0 \mathrm{wt} \% \mathrm{NiO}$ (Fig. 3b). The grain growth behavior indicates a qualitative difference in the SSRS sintering process between samples with low and high $\mathrm{NiO}$ addition, which is most probably related to the amount of transient liquid phase formed. Characteristic differences are also observed in the microstrain that is extracted from the XRD peak widths according to the Williamson-Hall 
(a)
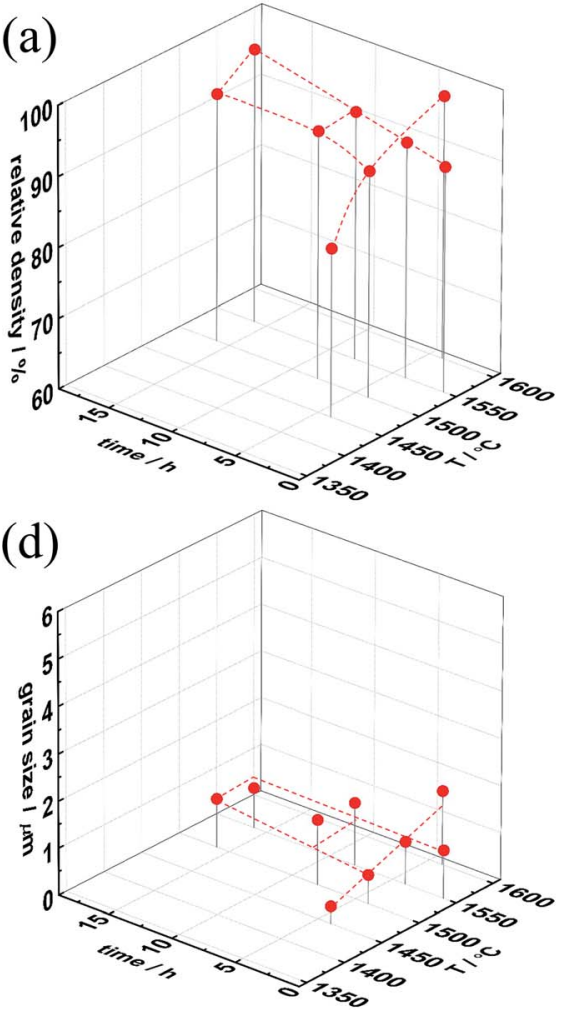

(b)

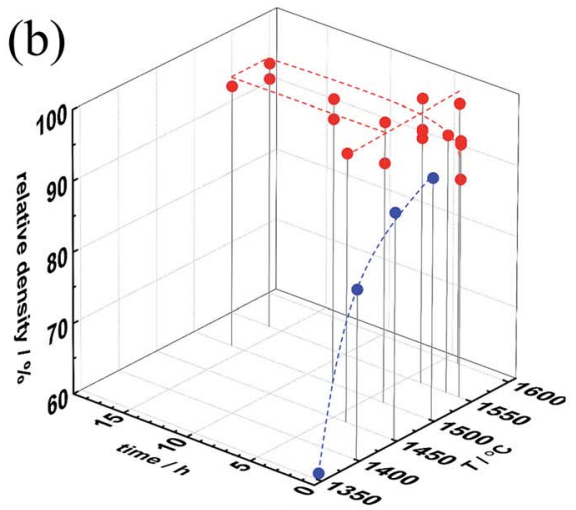

(e)

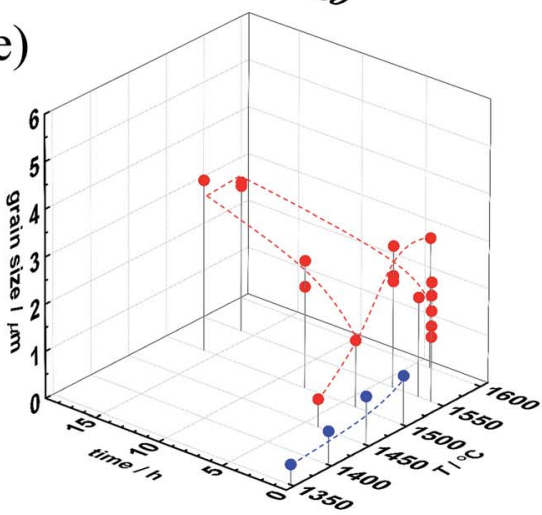

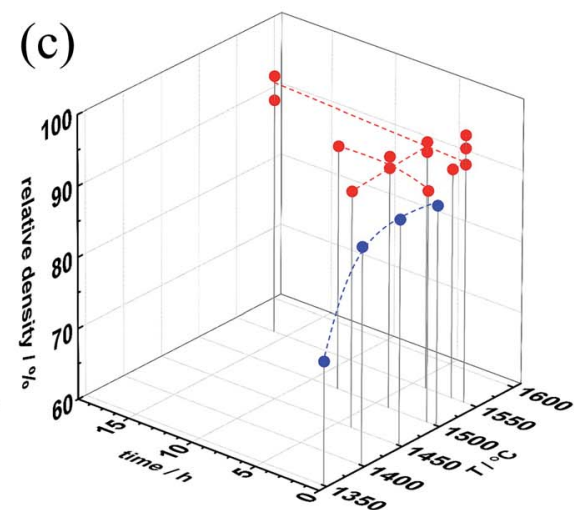

(f)

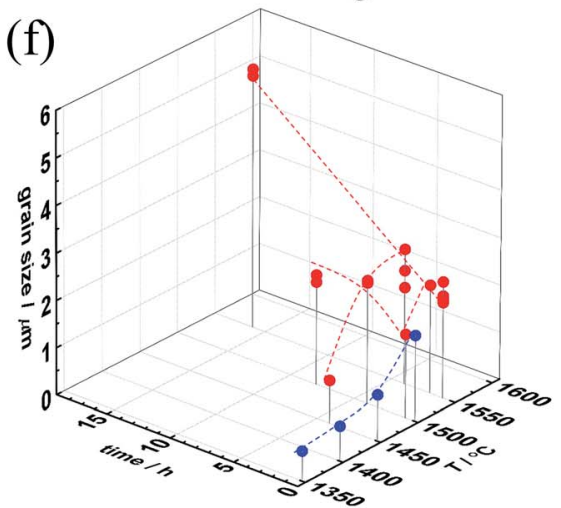

Fig. 2 Relative density (top) and grain size (bottom) as function of sintering temperature and soaking time with (a and d) $0.25 \mathrm{wt} \% \mathrm{NiO}$, (b and e) $0.5 \mathrm{wt} \% \mathrm{NiO}$, and (c and f) $1.0 \mathrm{wt} \% \mathrm{NiO}$. Red and blue dots represent samples with standard $\left(200 \mathrm{~K} \mathrm{~h}^{-1}\right)$ and fast $\left(600 \mathrm{~K} \mathrm{~h}^{-1}\right)$ heating/cooling rate. The dashed lines are only a guide to the eye.
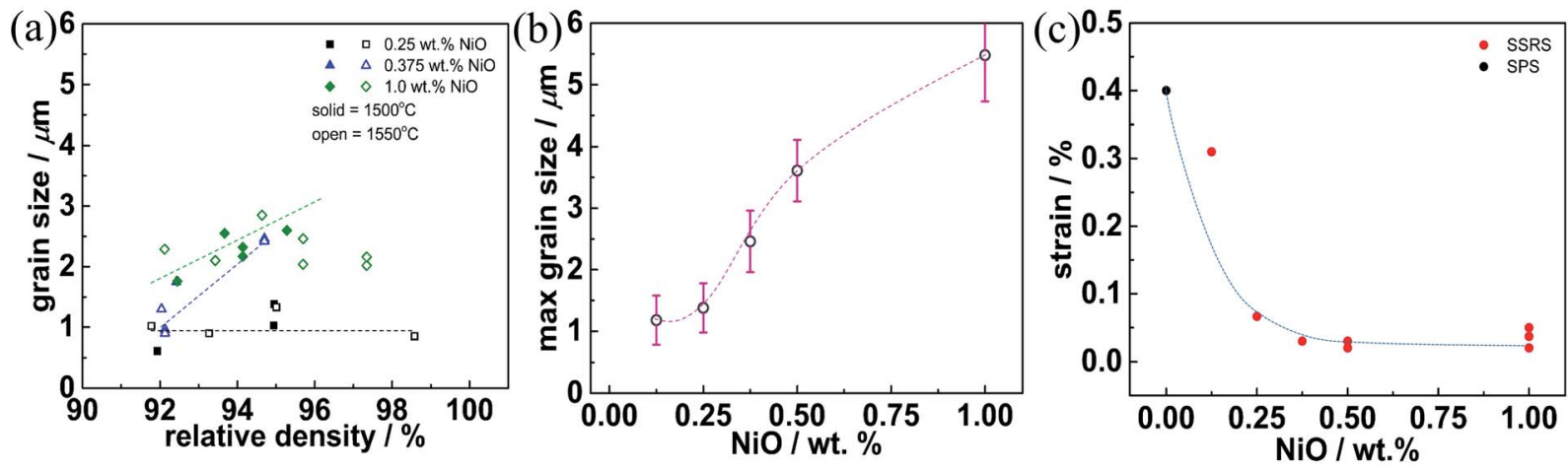

Fig. 3 (a) Grain size plotted versus relative density for different NiO content. (b) Maximum grain size as function of NiO content. (c) Microstrain extracted by the Williamson-Hall method for samples sintered at $1550{ }^{\circ} \mathrm{C} 4 \mathrm{~h}$ for different NiO content (the NiO-free SPS sample was postannealed at $1500^{\circ} \mathrm{C} 4 \mathrm{~h}$ ). The dashed lines are only a guide to the eye.

method $^{39}$ (Fig. 3c). This micro-strain is high for the Ni-free SPS sample as well as for the SSRS sample with $0.125 \mathrm{wt} \% \mathrm{NiO}$ (independent of soaking time). The strain decreases strongly for $0.25 \mathrm{wt} \% \mathrm{NiO}$, and then remains negligible for higher $\mathrm{NiO}$ contents. This indicates that the ceramics with high $\mathrm{NiO}$ content have less local distortions/inhomogeneities (e.g. from inhomogeneous B-site cation distribution) within the crystallites.

The dependence of grain growth as well as microstrain on $\mathrm{NiO}$ addition indicates that a certain threshold value of liquid phase volume is required which is met at about $0.3 \mathrm{wt} \% \mathrm{NiO}$.
Depending on the composition of the liquid phase (closer to $\mathrm{BaNiO}_{2}$ or to $\mathrm{BaY}_{2} \mathrm{NiO}_{5}$ ), $0.3 \mathrm{wt} \% \mathrm{NiO}$ corresponds to 0.9$1.8 \mathrm{vol} \%$ of liquid phase. Owing to the moderate $\mathrm{Y}$ and NiO contents used in the present investigation, no direct traces of the solidified liquid phase were detected in XRD or SEM, neither in oven-cooled nor in the quenched samples of Section 3.2 (residues of $\mathrm{BaY}_{2} \mathrm{NiO}_{5}$ are typically found for $\mathrm{Y}$ - and Ni-rich compositions ${ }^{20,59}$ ). Nevertheless, the sintering behavior clearly indicates the presence of a transient liquid phase for NiO contents above $0.25 \mathrm{wt} \%$ (strongly increased densification and grain growth, decrease of microstrain). The higher the volume 

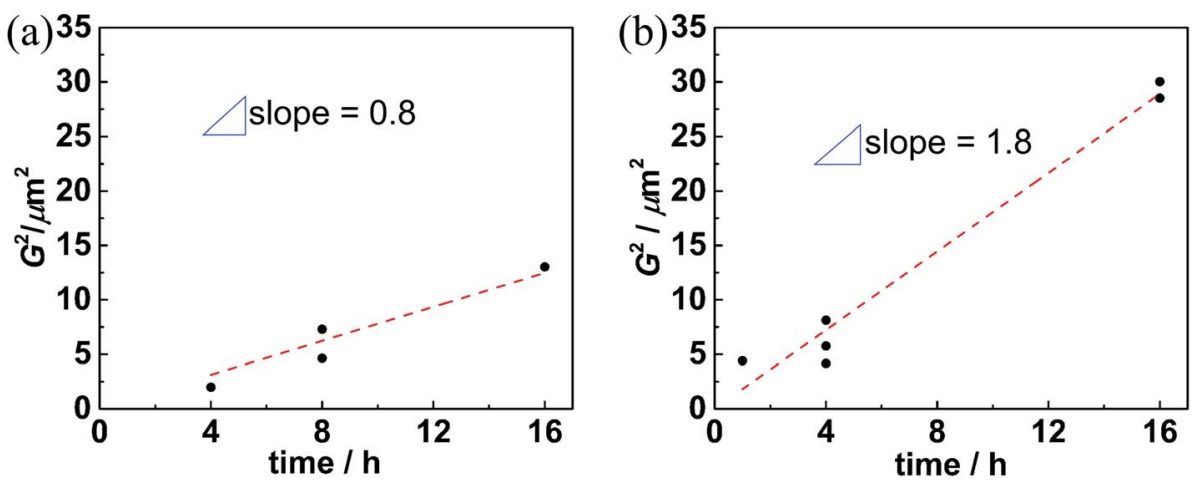

Fig. 4 Squared grain size of SSRS samples plotted versus soaking time for (a) $0.5 \mathrm{wt} \% \mathrm{NiO}$ at $1500{ }^{\circ} \mathrm{C}$, (b) $1.0 \mathrm{wt} \% \mathrm{NiO}$ at $1550{ }^{\circ} \mathrm{C}$.

fraction of the liquid phase, which probably also dissolved some $\mathrm{Zr}^{4+}, \mathrm{Ce}^{4+}$ and thus supplies a fast diffusion path for all cations, the faster the densification and the larger the grain size.

So far, the advantages of NiO addition in SSRS can be summarized as follows: (i) improved densification, (ii) promoted grain growth, and (iii) decreased microstrain indicating more homogeneous cation distribution. These advantages become effective in SSRS of $\mathrm{Ba}_{1.015} \mathrm{Zr}_{0.664} \mathrm{Ce}_{0.20} \mathrm{Y}_{0.136} \mathrm{O}_{3-\delta}$ for $\mathrm{NiO}$ contents of at least $0.375 \mathrm{wt} \% \mathrm{NiO}$.

It is interesting to analyze the grain growth kinetics in more detail. Fig. 4 shows that the grain size follows the frequently observed grain growth relation: ${ }^{40}$

$$
G^{n}-G_{0}^{n}=k t
$$

with an exponent of $n=2$, where $G$ is the grain size at time $t, G_{0}$ the initial grain size (for SSRS where the final phase is formed only during the sintering, $G_{0}$ is not a very well-defined quantity, but for the conditions of Fig. 4 its value is negligible anyway), and $k$ the grain growth rate constant. This relation was originally derived for sintering in absence of a liquid phase, but it is also applicable for liquid phase sintering (see review ${ }^{\mathbf{4 1}}$ and references therein). In particular within the solution-reprecipitation model, an exponent of 2 corresponds to grain growth limitation by the solution/reprecipitation at the solid-liquid interface (typical for small liquid-phase volume fraction, i.e., short diffusion lengths in the liquid). For large liquid volume fractions with long diffusion lengths an exponent of 3 would be expected. In the present case the liquid fraction of 1.5-6.0 vol\% for $0.5-1.0 \mathrm{wt} \% \mathrm{NiO}$ is comparably small, thus the observed exponent of 2 in Fig. 4 matches to the expectation.

In literature, systems are reported in which comparably small volume fractions of liquid phase suffice for effective sintering. Sintering of $\mathrm{Al}_{2} \mathrm{O}_{3}$ with a glassy liquid phase showed the strongest acceleration of densification at 1-5 vol\% of the glassy phase. ${ }^{42}$ For Gd-doped ceria, an addition of $2 \mathrm{~mol} \% \mathrm{CoO}$ strongly increased the grain growth, ${ }^{43}$ however the liquid phase formation was not unambiguously proven. For sintering of $\mathrm{BaTiO}_{3}, 1 \mathrm{wt} \% \mathrm{LiF}$ liquid phase increased densification without grain growth, while $2-5 \mathrm{wt} \% \mathrm{LiF}$ were required to increase also the grain size. ${ }^{\mathbf{4}}$ The liquid phase fraction in the present investigation is in a comparable range and expected to increase with NiO content. Correspondingly, with a larger NiO addition the increased amount of liquid phase can wet a larger area of forming perovskite grains, and thus accelerate the overall grain growth and densification.

Fig. 5 shows the squared grain size at fixed soaking time as function of inverse temperature. The open symbols represent $\mathrm{Ni}$-free samples from conventional sintering collected from literature. While the individual data have some scatter, the fitted activation energy of $3.7 \mathrm{eV}$ agrees well to the activation energies of cation GB diffusion in $\mathrm{BaZrO}_{3}(3.7 \mathrm{eV}$ for $\mathrm{Zr}, 3.0 \mathrm{eV}$ for $\mathrm{Ba},{ }^{52,53}$ bulk activation energies amount to $4.5 \mathrm{eV}$ for $\mathrm{Zr}, 4 \mathrm{eV}$ for $\mathrm{Ba}$ ). The activation energy increases to $5.3 \mathrm{eV}$ for SSRS samples with $0.25 \mathrm{wt} \% \mathrm{NiO}$ addition, and further increases to $6.2 \mathrm{eV}$ with higher $\mathrm{NiO}$ content. At first glance it might appear surprising that the increased grain growth rates of these samples come together with an increased activation energy. However, one reason might be that the solubility of Ce and $\mathrm{Zr}$ in the $(\mathrm{Ba}, \mathrm{Ni}, \mathrm{Y}) \mathrm{O}_{x}$ liquid phase could have a strong temperature

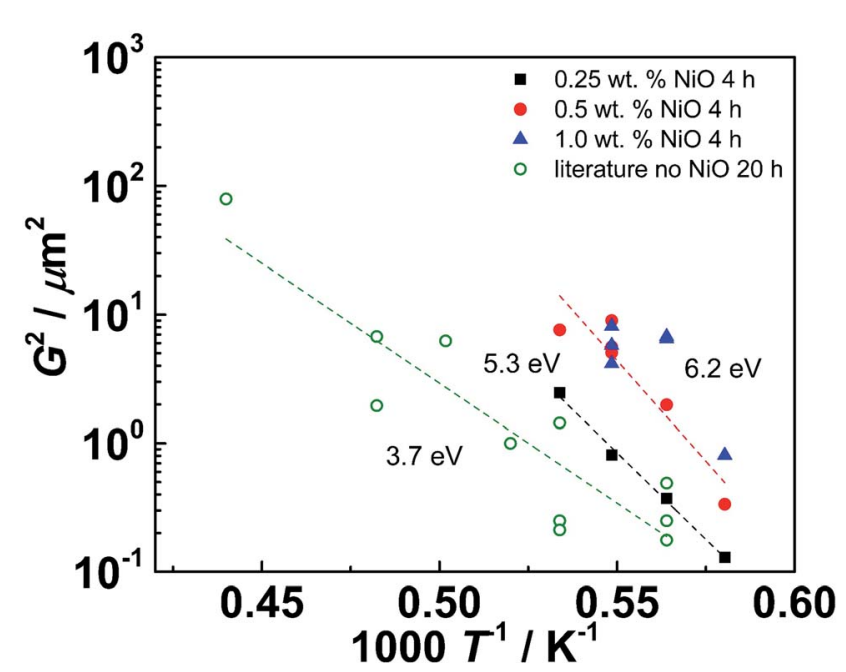

Fig. 5 Squared grain size at fixed soaking time plotted as function of inverse temperature. Open symbols: conventionally sintered $\mathrm{Ni}$-free $\mathrm{Ba}(\mathrm{Zr}, \mathrm{Y}) \mathrm{O}_{3-\delta}$ samples with 5-20 at\% $\mathrm{Y}$, soaking time 20-24 h, data taken from literature. ${ }^{18,21,36,45-51}$ Solid symbols: SSRS BZCY samples with different $\mathrm{NiO}$ content from present investigation (20 at\% Ce, 13.6 at\% Y), soaking time $4 \mathrm{~h}$. 


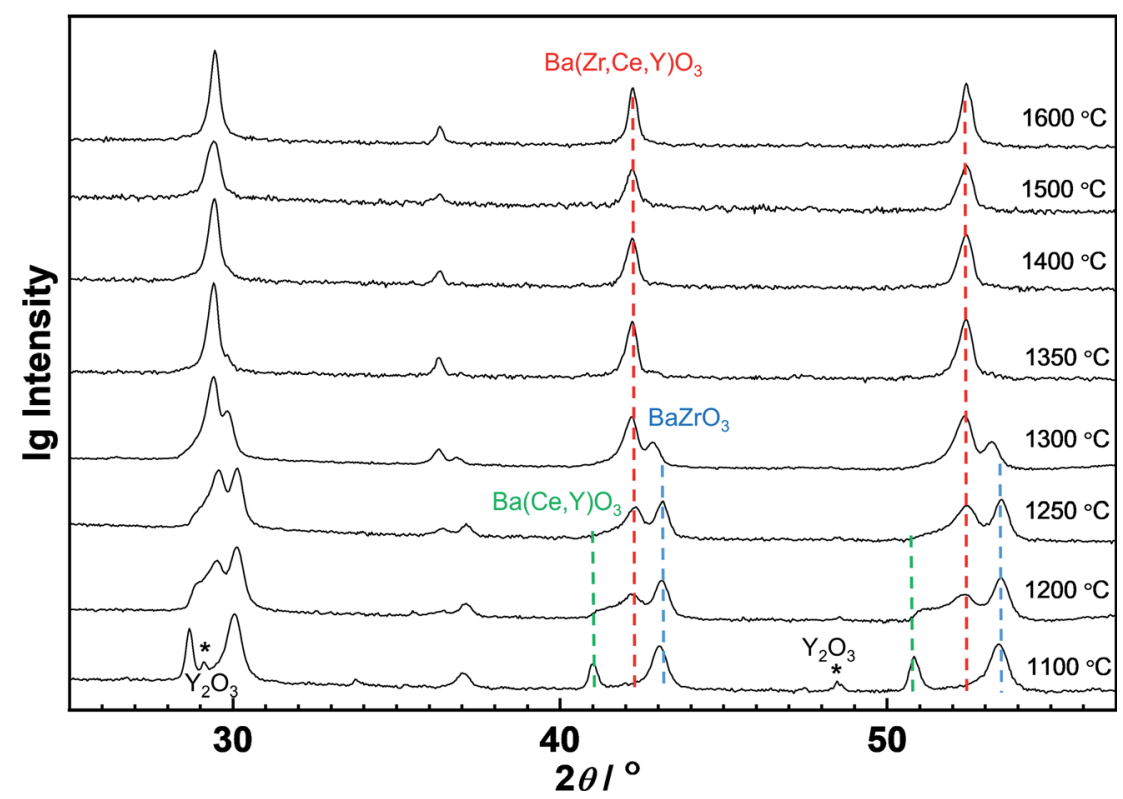

Fig. 6 XRD patterns of $\mathrm{BZCY}$ with $2.0 \mathrm{wt} \% \mathrm{NiO}$ addition sintered at different temperature for $10 \mathrm{~min}$. The undoped, $\mathrm{Y}$-free $\mathrm{BaZrO},(\mathrm{Ce}, \mathrm{Y})$-rich $\mathrm{BZCY}$ and final homogeneous BZCY phase are assigned based on the lattice parameters.

dependence, and a higher Ce, $\mathrm{Zr}$ concentration in the melt will allow for faster perovskite phase reprecipitation. The practical consequence of this observation is that a moderate increase of sintering temperature could be more suitable for increasing grain growth than an increased $\mathrm{NiO}$ addition or soaking time. This observation is also relevant for the sintering of anode/ electrolyte assemblies, where long soaking times are shown to be detrimental..$^{63}$

\subsection{Phase evolution}

A specific feature of the solid state reactive sintering is that the final perovskite phase is not pre-formed in the starting powder. Either the components of the perovskite phase dissolve into the $(\mathrm{Ba}, \mathrm{Ni}, \mathrm{Y}) \mathrm{O}_{x}$ liquid phase directly from the educts $\left(\mathrm{BaCO}_{3}, \mathrm{Y}_{2} \mathrm{O}_{3}\right.$, $\mathrm{CeO}_{2}, \mathrm{ZrO}_{2}$ ), or small perovskite crystallites formed at the contacts between $\mathrm{BaCO}_{3}$ and $\left(\mathrm{Y}_{2} \mathrm{O}_{3}, \mathrm{CeO}_{2}, \mathrm{ZrO}_{2}\right)$ grains will be available. They are expected to dissolve more easily than large
BZCY crystallites (when the perovskite phase is formed in the preceding solid state reaction, and $\mathrm{NiO}$ added as a conventional sintering aid). Thus, the SSRS procedure for BZCY beneficially combines liquid-phase formation with facilitated dissolution of precursor phases. Quenching experiments were performed to further elucidate the SSRS mechanism. Fig. 6 shows the XRD pattern evolution for samples with $2.0 \mathrm{wt} \% \mathrm{NiO}$ addition. At about $1000{ }^{\circ} \mathrm{C}$ (not shown), two perovskite phases start to form. At $1100{ }^{\circ} \mathrm{C}$, only a small $\mathrm{Y}_{2} \mathrm{O}_{3}$ residue from the raw materials remains, which disappears above $1200^{\circ} \mathrm{C}$. One of the perovskite phases can be assigned to essentially undoped, almost Y-free $\mathrm{BaZrO}_{3}$ based on its lattice constant of $4.20 \AA$, which is very close to that of undoped $\mathrm{BaZrO}_{3}$ of $4.195 \AA$ (using the dependence of the lattice parameter on $\mathrm{Y}$ concentration as reported e.g. in ref. 54 yields an estimated $\mathrm{Y}$ content of this phase of $\sim 3 \mathrm{~mol} \%$ ). The phase with the larger lattice constant corresponds to BZCY with a high Ce and Y content ( $c f$. also Fig. 8).

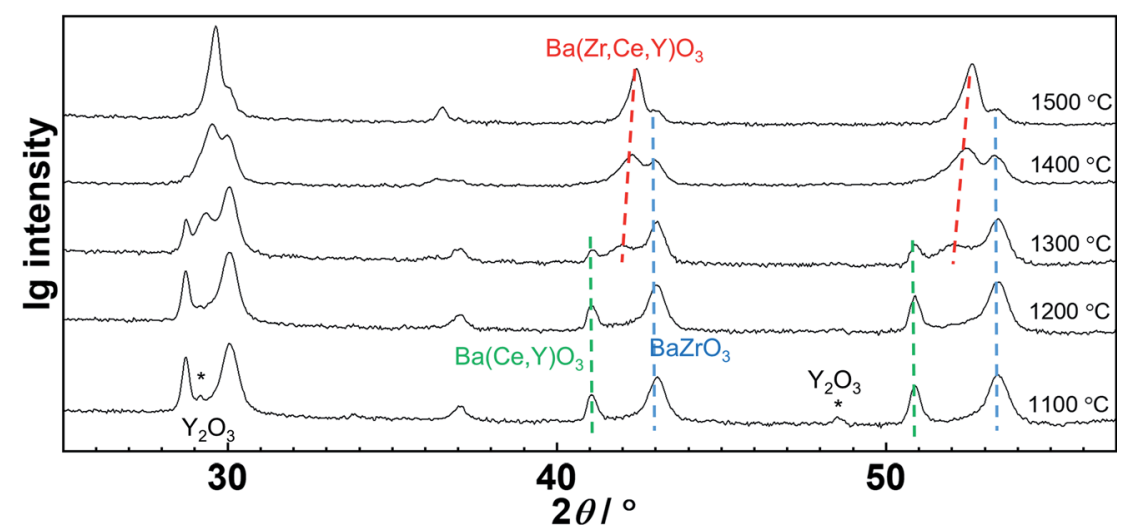

Fig. 7 XRD patterns of BZCY with 0.125 wt\% $\mathrm{NiO}$ addition sintered at different temperature for $10 \mathrm{~min}$. 

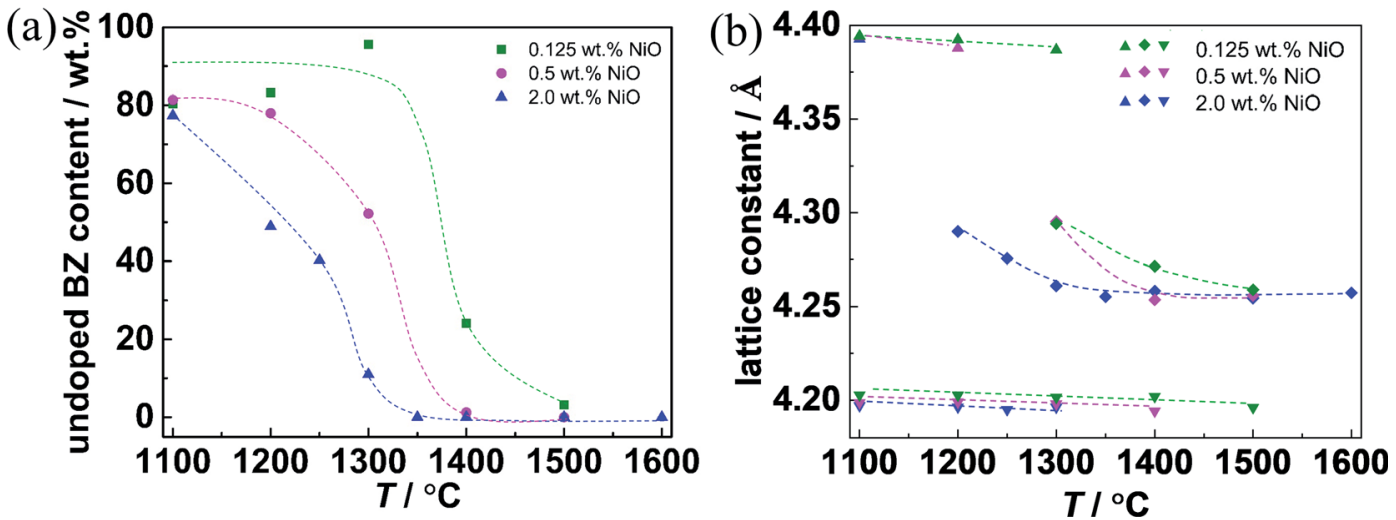

Fig. 8 (a) Content of the undoped (almost Y-free) BZ phase. (b) Lattice constants of BZ (triangles down), (Ce,Y)-rich BZCY (triangles up), and BZCY with final cation composition (diamonds) with different NiO addition sintered for 10 min at different temperatures. Dashed lines are only a guide for the eye.

$\mathrm{BaCeO}_{3}$ is actually orthorhombic but this is hardly detectable for the present large peak width. Owing to the insensitivity of the $\mathrm{BaCeO}_{3}$ lattice parameter to $\mathrm{Y}$ substituting for $\mathrm{Ce}^{55}$ the $\mathrm{Y}$ content in this phase cannot be estimated. We conclude that this phase is largely $\mathrm{Zr}$-free, as presence of $\mathrm{Zr}$ should strongly decrease the lattice constant. With increasing temperature, Ce and $\mathrm{Y}$ ions gradually dissolve in the transient liquid phase and distribute more homogeneously throughout the grains. At temperatures above $1350{ }^{\circ} \mathrm{C}$, only one single perovskite BZCY phase is left.

The behavior with a low NiO content of $0.125 \mathrm{wt} \%$ is shown in Fig. 7. The perovskite phases also start to form above $1000{ }^{\circ} \mathrm{C}$, with some $\mathrm{Y}_{2} \mathrm{O}_{3}$ residue. In this sample even three perovskite phases $\left(\mathrm{BaZrO}_{3},(\mathrm{Ce}, \mathrm{Y})\right.$-rich $\mathrm{BZCY}$, and homogeneous $\left.\mathrm{BZCY}\right)$ are present in an extended temperature range, and more than $1500{ }^{\circ} \mathrm{C}$ are required to reach a single homogeneous BZCY phase. Clearly, a low NiO content (low transient liquid phase volume) makes it more difficult to obtain a homogeneously distributed B site cation occupancy.

The content of undoped BZ and the lattice constants of the quenched samples are summarized in Fig. 8. For $2.0 \mathrm{wt} \% \mathrm{NiO}$, the undoped $\mathrm{BZ}$ phase fraction rapidly drops from $\approx 80 \%$ to lower values, and vanishes at $1350^{\circ} \mathrm{C}$. For $0.5 \mathrm{wt} \% \mathrm{NiO}$ the same process is shifted to about $50 \mathrm{~K}$ higher temperatures. In contrast, for $0.125 \mathrm{wt} \% \mathrm{NiO}$ the undoped $\mathrm{BZ}$ fraction remains almost unchanged up to $1300{ }^{\circ} \mathrm{C}$, and a small fraction is still present after $10 \mathrm{~min}$ at $1500^{\circ} \mathrm{C}$. For all NiO contents, the lattice constant of the undoped BZ and the (Ce,Y)-rich BZCY phase remains unchanged. The lattice constant corresponding to the middle perovskite peak gradually approaches the value of the homogeneous BZCY phase of $4.26 \AA$ at or above $1400{ }^{\circ} \mathrm{C}$. Interestingly, for a given $\mathrm{NiO}$ content the (Ce,Y)-rich $\mathrm{BZCY}$ phase vanishes at lower $T$ than the $\mathrm{BZ}$ phase, i.e. it seems to dissolve more easily in the transient liquid phase. The comparison for the different NiO contents shows that a higher liquid phase volume facilitates the cation transport, and the perovskite phase becomes uniform more easily.

For selected samples, the element distribution and possible remainders of the transient liquid phase were investigated by TEM-EELS. Fig. 9 shows the TEM-EELS mapping for the sample with $2.0 \mathrm{wt} \% \mathrm{NiO}$ quenched from $1250{ }^{\circ} \mathrm{C}$. There is a clear element inhomogeneity on a $100 \mathrm{~nm}$ length scale. While some grains show high Ce content, others are high in $\mathrm{Ba}$ and $\mathrm{Zr}$ (owing to the low Y concentration, the Y map is too noisy for any conclusions). This pronounced inhomogeneity agrees with the XRD results in Fig. 6 (presence of an undoped BZ and a Ce-rich (a)

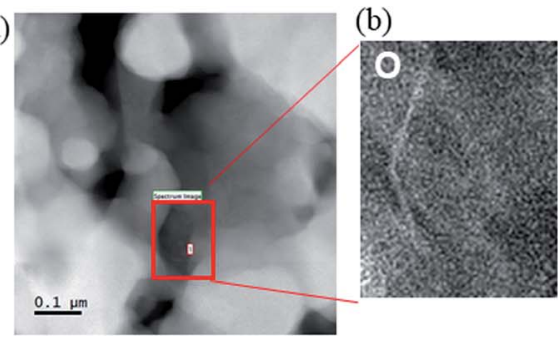

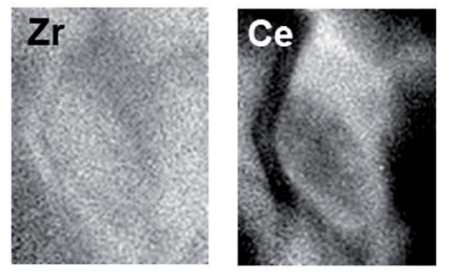

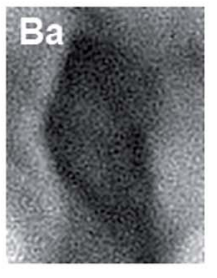

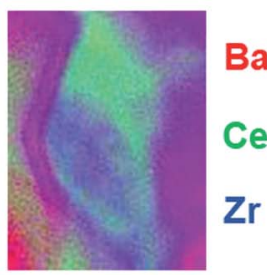

$\mathrm{Ba}$

$\mathrm{Ce}$

$\mathrm{Zr}$

Fig. 9 (a) HAADF image, and (b) corresponding element mapping TEM-EELS measurement. The rectangle indicated in (a) is the mapping area. The quenched sample with $2.0 \mathrm{wt} \% \mathrm{NiO}$ addition was sintered at $1250{ }^{\circ} \mathrm{C}$ for 10 min, according to XRD it contains BZ and BZCY perovskite phases. 
BZCY perovskite phase at low temperature). Further TEM results are given in Fig. S7, S8† and ref. 56.

\subsection{Proton uptake}

So far it might seem that the higher the NiO addition is, the better are BZCY processing (lower sintering temperature) and properties (larger grains and improved cation homogeneity). However, a clear detrimental effect of sintering additives such as $\mathrm{NiO}, \mathrm{CuO}, \mathrm{ZnO}$ on the proton conductivity of $\mathrm{Y}$-doped $\mathrm{BaZrO}_{3}$ has been shown e.g. in ref. 23, 26 and 29. For $\mathrm{BaZr}_{1-x} \mathrm{Y}_{x} \mathrm{O}_{3}$, a systematic decrease of proton uptake with increasing $\mathrm{NiO}$ addition was found. ${ }^{35,57,58}$

Fig. 10b shows that for the Ni-free sample the maximum proton uptake almost equals the nominal dopant concentration $=13.6$ at $\%$ at $300{ }^{\circ} \mathrm{C}$. This holds also for Ni-containing samples when $\mathrm{Ni}$ is incorporated as substitutional dopant on the B-site (i.e., $\mathrm{BaZr}_{1-x-y} \mathrm{Y}_{x} \mathrm{Ni}_{y} \mathrm{O}_{3}$ ), and is independent of the sintering method (SPS or conventional sintering). However, Fig. 10a demonstrates that when $\mathrm{NiO}$ is added in excess to the perovskite's cation composition (i.e., $\mathrm{BaZr}_{1-x} \mathrm{Y}_{x} \mathrm{O}_{3}+y \mathrm{NiO}$ ) as typical for the SSRS process, the maximum proton uptake decreases. This decrease is the more severe the higher the NiO addition is, e.g. for $1 \mathrm{wt} \% \mathrm{NiO}$ the proton uptake decreases by about one half ( $1 \mathrm{wt} \% \mathrm{NiO}$ corresponds to $\approx 4.0$ at $\% \mathrm{Ni}$ on B site if fully incorporated into the perovskite lattice).
The mass action constant for the hydration reaction $K_{\text {hydrat }}$ is calculated according to:

$$
\begin{gathered}
\mathrm{H}_{2} \mathrm{O}+\mathrm{V}_{\mathrm{O}}^{*}+\mathrm{O}_{\mathrm{O}}^{\times} \rightleftharpoons 2 \mathrm{OH}_{\mathrm{O}}^{\cdot} \\
K_{\text {hydrat }}=\frac{\left[\mathrm{OH}_{\mathrm{O}}^{\cdot}\right]^{2}}{p_{\mathrm{H}_{2} \mathrm{O}}\left[\mathrm{V}_{\mathrm{O}}^{*}\right]\left[\mathrm{O}_{\mathrm{O}}^{\times}\right]}
\end{gathered}
$$

with $\left[\mathrm{V}_{\mathrm{O}}^{*}\right]=0.5\left[\mathrm{~A}^{\prime}\right]-0.5\left[\mathrm{OH}_{\mathrm{O}}^{*}\right]$, where $\left[\mathrm{A}^{\prime}\right]=\left[\mathrm{Y}_{\mathrm{Zr}}^{\prime}\right]$ is the nominal acceptor concentration. The SPS sample without Ni shows a linear Van't Hoff plot (Fig. S9†), which indicates its ideal hydration behavior. SPS samples with substitutional Ni on the B site exhibit a slight bending appearing only at comparably low temperatures (below $420{ }^{\circ} \mathrm{C}$ ). However, SSRS samples with excess NiO exhibit strongly bent Van't Hoff plots (Fig. S10a $\dagger$ ), corresponding to the fact that the maximum proton uptake is significantly lower than the nominal acceptor concentration (Fig. 10a). However, linear Van't Hoff plots can be obtained when a decreased effective dopant concentrations $\left[\mathrm{A}^{\prime}{ }_{\text {eff }}\right]$ is applied (Fig. S10b, $\dagger$ details of $\left[\mathrm{A}^{\prime}{ }_{\text {eff }}\right]$ determination are described there). The corresponding $\left[\mathrm{A}^{\prime}\right.$ eff $]$ values are plotted in Fig. 10c. $\left[\mathrm{A}^{\prime}{ }_{\text {eff }}\right]$ shows only a very slight decrease with increasing NiO content for samples with $\mathrm{Ni}$ on the B site, whereas it decreases strongly for SSRS samples with excess NiO. The decreased effective acceptor concentration can be attributed to the fact that the formation of a $(\mathrm{Ba}, \mathrm{Ni}, \mathrm{Y}) \mathrm{O}_{x}$ liquid phase binds some $\mathrm{BaO}$ which is then unavailable for the perovskite's A site. It has
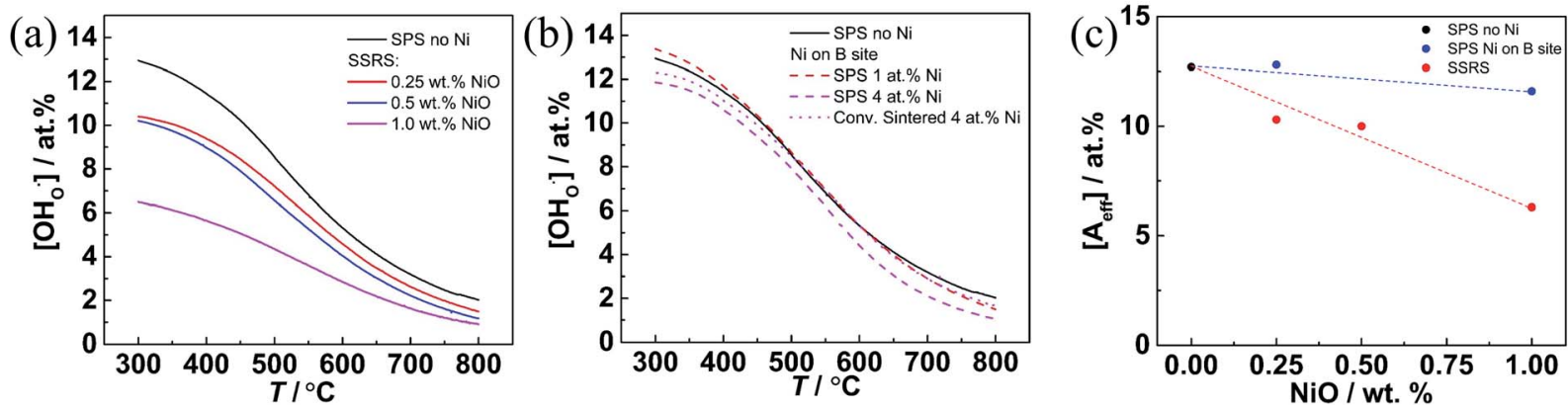

Fig. 10 Proton uptake of $\mathrm{Ba}_{1.015} \mathrm{Zr}_{0.664} \mathrm{Ce}_{0.20} \mathrm{Y}_{0.136} \mathrm{O}_{3-\delta}$ with different $\mathrm{NiO}$ content. (a) $\mathrm{Ni}$-free SPS sample and SSRS samples with excess Ni. (b) SPS samples with substitutional Ni. (c) Effective acceptor dopant concentration vs. NiO content. The dashed lines are only a guide to the eye.
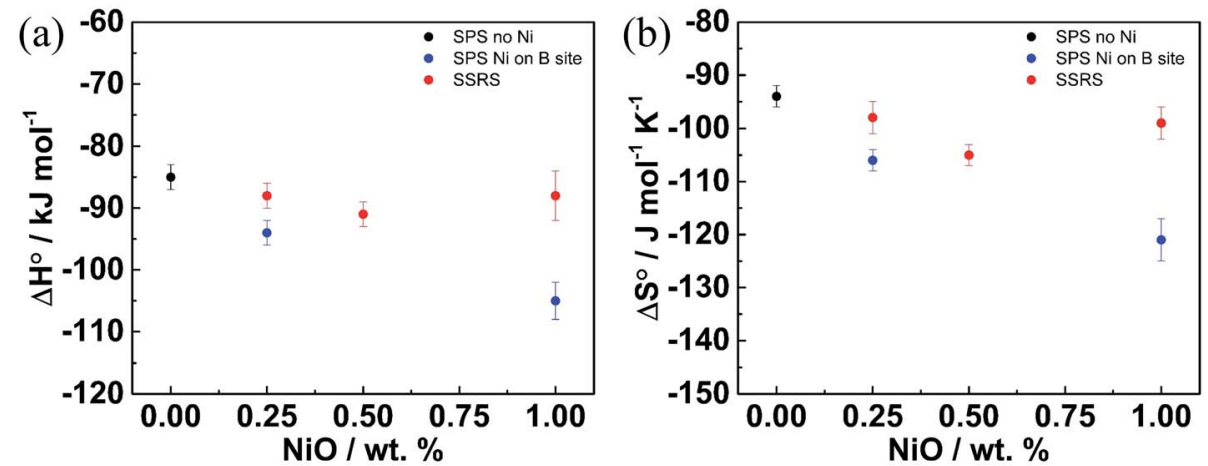

Fig. 11 (a) Standard hydration enthalpy and (b) hydration entropy of BZCY Ni-free sample, bulk Ni samples and SSRS samples. $\Delta H^{0}$ and $\Delta S^{0}$ were calculated from the Van't Hoff plots (using the $\left[\mathrm{A}^{\prime}\right.$ eff] values) in the range of $350-800{ }^{\circ} \mathrm{C}$. 

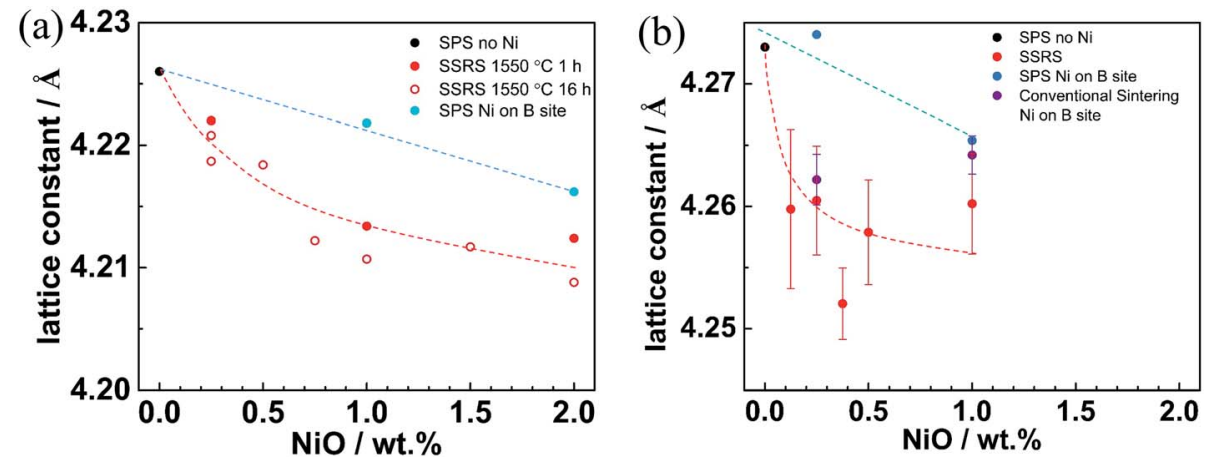

Fig. 12 Lattice constant versus NiO addition for (a) BZY (data taken from ref. 35), (b) BZCY samples.

been shown that Ba deficiency leads to a partial change of $\mathrm{Y}$ from being an acceptor on the B site to donor on the A site, ${ }^{59}$ which decreases the effective acceptor concentration. Such a process is in line with the decreased lattice constants of SSRS samples in Fig. 12 because of the smaller ion radius of $\mathrm{Y}^{3+}$ compared to $\mathrm{Ba}^{2+}$.

Fig. 11 shows the standard hydration enthalpies $\left(\Delta H^{0}\right)$ and entropies $\left(\Delta S^{0}\right)$ for samples without $\mathrm{Ni}$, with $\mathrm{Ni}$ on $\mathrm{B}$ site, and with excess $\mathrm{NiO}$ as extracted from the linear Van't Hoff plots (using the $\left[\mathrm{A}^{\prime}{ }_{\text {eff }}\right]$ values). The SSRS samples do not exhibit systematic changes of $\Delta H^{0}$ and $\Delta S^{0}$. In contrast, for samples with substitutional Ni on the B site $\Delta H^{0}$ and $\Delta S^{0}$ become more negative with increasing $\mathrm{Ni}$ content, which can possibly be ascribed to proton trapping at doubly negatively charged $\mathrm{Ni}_{\mathrm{Zr}}^{\prime \prime}$ defects. The strongly decreased proton uptake in SSRS samples with excess NiO arises mainly from the decreased effective acceptor dopant, rather than from modified thermodynamic parameters.

The NiO addition also influences the lattice constant, as shown in Fig. 12. For both BZY and BZCY, it decreases linearly with $\mathrm{Ni}$ content for substitutional $\mathrm{Ni}$ (smaller ion radius of $\mathrm{Ni}^{2+}$ compared to $\mathrm{Zr}^{4+}$ ), whereas it decreases more strongly for excess $\mathrm{NiO}$ (partial occupation of A site by $\mathrm{Y}^{3+}$ ). For BZCY the lattice constant drops significantly from 0 to $0.125 \mathrm{wt} \% \mathrm{NiO}$ addition, and afterwards remains almost constant but with larger scatter. This might be related to a higher reactivity of Ce-rich perovskites with the forming $(\mathrm{Ba}, \mathrm{Y}, \mathrm{Ni}) \mathrm{O}_{x}$ melt, and the fact that with three $\mathrm{B}$ site cations and a homogeneous site occupation it is more difficult to achieve a homogeneous composition, as discussed in Section 3.2.

The clear difference in the behavior of samples with excess $\mathrm{Ni}$ or substitutional $\mathrm{Ni}$ with respect to hydration and lattice parameters indicates that Ni in SSRS does not significantly occupy the perovskite's B site. Instead, Ni rather extracts Ba out of the perovskite lattice to form the transient $(\mathrm{Ba}, \mathrm{Y}, \mathrm{Ni}) \mathrm{O}_{x}$ liquid phase during SSRS. A more detailed defect chemical discussion of this process is given in ref. 37 .

\subsection{Concluding discussion}

The possible sintering mechanism of SSRS as concluded from the former discussion is schematically shown in Fig. 13. Direct contact points of $\mathrm{BaO}$ with $\mathrm{ZrO}_{2}$ and $\mathrm{CeO}_{2}$ lead to the formation of Zr-rich and Ce-rich perovskite grains (Fig. 6-8). The key of SSRS sintering of highly refractory $\mathrm{Ba}(\mathrm{Zr}, \mathrm{Ce}, \mathrm{Y}) \mathrm{O}_{3}$ perovskites is the formation of a transient liquid phase, which allows for comparably fast cation transport which facilitates densification, grain growth, and homogenization of B site cation composition. It is rich in $\mathrm{Ba}, \mathrm{Ni}$ and $\mathrm{Y}$, and forms more easily when $\mathrm{NiO}$ is added to the mixture of $\mathrm{BaO}$ (from $\mathrm{BaCO}_{3}$ ), $\mathrm{ZrO}_{2}, \mathrm{CeO}_{2}$ and $\mathrm{Y}_{2} \mathrm{O}_{3}$ starting materials, than when $\mathrm{NiO}$ is added to an already formed BZCY perovskite phase. The melt has a solubility for $\mathrm{Zr}^{4+}, \mathrm{Ce}^{4+}$ (probably increasing with temperature) and thus allows for grain growth (Ostwald ripening) by a solution-reprecipitation mechanism. The final product are large BZCY grains with close to equilibrium shape.

The transient liquid phase is formed at low temperature and is continuously consumed during the sintering with increasing temperature and time. $\mathrm{BaNiO}_{2}$ is thermally stable even above $1800{ }^{\circ} \mathrm{C}$ (it melts at about $1200{ }^{\circ} \mathrm{C}$ (ref. 60) but does not decompose into phases with different cation composition), while $\mathrm{BaY}_{2} \mathrm{NiO}_{5}$ was reported to decompose to $\mathrm{Y}_{2} \mathrm{O}_{3}, \mathrm{BaO}$ and $\mathrm{NiO}$ at $1500{ }^{\circ} \mathrm{C} .{ }^{61}$ With increasing progress of the BZCY phase formation, the $\mathrm{Ba}$ is expected to be at least partially reincorporated into the perovskite lattice. ${ }^{20}$ However, the decreased effective acceptor concentration as well as the decreased lattice constant suggest that the BZCY phase retains some Ba deficiency.

The thermodynamic data and the lattice constants of the SSRS samples (Fig. 10-12) clearly differ from samples with substitutional $\mathrm{Ni}$ on the $\mathrm{B}$ site. At the end of SSRS, Ni was detected in the GB regions. ${ }^{\mathbf{2 1}, 52}$ Both findings together indicate that most Ni remains close to the grain boundaries, and the reincorporation of the liquid phase constituents into the perovskite lattice ${ }^{32}$ occurs only in part. Overall, SSRS is a complex process and the detailed nature of the transient liquid phase $(\mathrm{Ba}, \mathrm{Ni}, \mathrm{Y}) \mathrm{O}_{x}$ remains to some degree elusive.

The liquid phase induced by $\mathrm{NiO}$ promotes cation transport and therefore results in much better densification, grain growth, and homogeneous perovskite phase at moderate temperature, which is beneficial for membrane fabrications. In full cells, the anode layer is usually composed of BZCY and 50$60 \mathrm{wt} \% \mathrm{NiO}$, providing an infinite source of $\mathrm{Ni}$ for the electrolyte layer. Ni can diffuse a few micrometers from the anode layer 


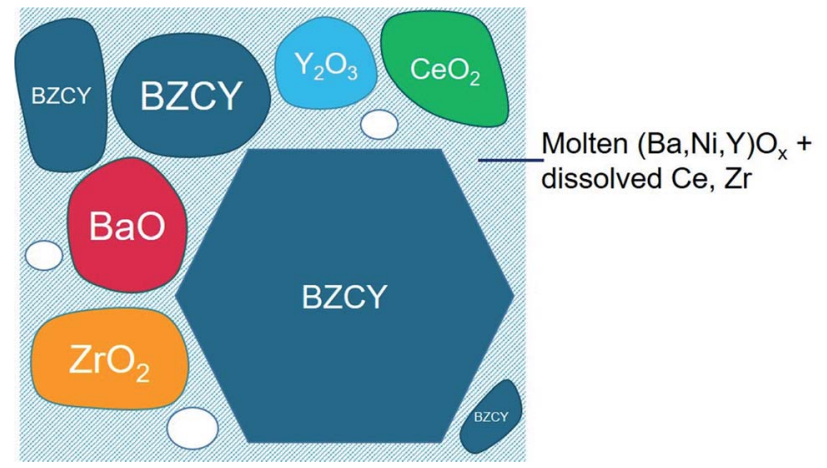

Fig. 13 Schematics of the SSRS sintering mechanism of BZCY.

into the electrolyte layer ${ }^{\mathbf{6 2 , 6 3}}$ even without $\mathrm{NiO}$ addition in the electrolyte, which can trigger SSRS. To have controlled conditions, it is advisable to deliberately add some NiO into the electrolyte.

However, too high $\mathrm{NiO}$ addition decreases the proton uptake (Fig. 10), and may lead to crack formation or electronic shortcircuiting in reducing conditions. An increased $\mathrm{Y}$ dopant concentration may partially compensate the decreased effective acceptor dopant concentration and result in a higher proton uptake. ${ }^{56}$ Based on its effects on sintering behavior and proton uptake of the present $\mathrm{Zr}$-rich composition, a NiO content of 0.4$0.5 \mathrm{wt} \%$ in the BZCY layer is recommended as a good compromise for BZCY membrane fabrication. For Ce-rich $\mathrm{BaZr}_{0.1^{-}}$ $\mathrm{Ce}_{0.7} \mathrm{Y}_{0.2} \mathrm{O}_{3-\delta}$, a similar NiO content has been recommended in ref. 33 .

\section{Summary}

The solid state reactive sintering process using NiO for $\mathrm{Ba}(\mathrm{Zr}, \mathrm{Ce}, \mathrm{Y}) \mathrm{O}_{3}$ proton conductors was investigated in detail. The results strongly indicate that solid state reactive sintering proceeds via the formation of a $(\mathrm{Ba}, \mathrm{Ni}, \mathrm{Y}) \mathrm{O}_{x}$ transient liquid phase, which facilitates homogeneous perovskite phase formation, ceramics densification, and grain growth (up to 6 $\mu \mathrm{m}$ with $1.0 \mathrm{wt} \% \mathrm{NiO}$ addition) at temperatures of 1400$1500{ }^{\circ} \mathrm{C}$, which are also feasible for the sintering of large-area membranes. Proton uptake measurements evidence a decrease of the effective acceptor concentration with increasing NiO addition, which is related to an incomplete reincorporation of $\mathrm{Ba}$ into the perovskite. From the comprehensive analysis of the $\mathrm{NiO}$ effects on sintering behavior and proton uptake, an addition of $0.4-0.5 \mathrm{wt} \%$ is recommended as a good balance between advantageous and detrimental effects.

\section{Conflicts of interest}

There are no conflicts to declare.

\section{Acknowledgements}

We thank Helga Hoier for XRD measurements, Armin Sorg for SPS sintering and Barbara Baum for sample cutting. We thank
Wilfried Sigle and Dan Zhou for TEM measurements and valuable discussions. This work was supported by BMBF project ProtOMem, 03SF0537C.

\section{References}

1 T. Norby, Solid State Ionics, 1999, 125, 1-11.

2 K. D. Kreuer, Annu. Rev. Mater. Res., 2003, 33, 333-359.

3 Y. Matsuzaki, Y. Tachikawa, T. Somekawa, T. Hatae, H. Matsumoto, S. Taniguchi and K. Sasaki, Sci. Rep., 2015, 5, 12640 .

4 H. Zhu and R. J. Kee, J. Electrochem. Soc., 2017, 164, F1400F1411.

5 C. Duan, J. Tong, M. Shang, S. Nikodemski, M. Sanders, S. Ricote, A. Almansoori and R. O'Hayre, Science, 2015, 349, 1321-1326.

6 S. Choi, C. J. Kucharczyk, Y. Liang, X. Zhang, I. Takeuchi, H.-I. Ji and S. M. Haile, Nat. Energy, 2018, 3, 202-210.

7 H. An, H.-W. Lee, B.-K. Kim, J.-W. Son, K. J. Yoon, H. Kim, D. Shin, H.-I. Ji and J.-H. Lee, Nat. Energy, 2018, 3, 870-875.

8 C. Duan, R. Kee, H. Zhu, N. Sullivan, L. Zhu, L. Bian, D. Jennings and R. O'Hayre, Nat. Energy, 2019, 4, 230-240.

9 S. Choi, T. C. Davenport and S. M. Haile, Energy Environ. Sci., 2019, 12, 206-215.

10 S. H. Morejudo, R. Zanón, S. Escolástico, I. Yuste-Tirados, H. Malerød-Fjeld, P. K. Vestre, W. G. Coors, A. Martínez, T. Norby, J. M. Serra and C. Kjølseth, Science, 2016, 353, 563-566.

11 H. Malerød-Fjeld, D. Clark, I. Yuste-Tirados, R. Zanón, D. Catalán-Martinez, D. Beeaff, S. H. Morejudo, P. K. Vestre, T. Norby, R. Haugsrud, J. M. Serra and C. Kjølseth, Nat. Energy, 2017, 2, 923-931.

12 K. D. Kreuer, Solid State Ionics, 1999, 125, 285-302.

13 S. M. Haile, D. L. West and J. Campbell, J. Mater. Res., 1998, 13, 1576-1595.

14 H. G. Bohn and T. Schober, J. Am. Ceram. Soc., 2004, 83, 768772.

15 M. Shirpour, R. Merkle, C. T. Lin and J. Maier, Phys. Chem. Chem. Phys., 2012, 14, 730-740.

16 C. Zuo, S. Zha, M. Liu, M. Hatano and M. Uchiyama, Adv. Mater., 2006, 18, 3318-3320.

17 K. H. Ryu and S. M. Haile, Solid State Ionics, 1999, 125, 355367.

18 J. Tong, D. Clark, M. Hoban and R. O'Hayre, Solid State Ionics, 2010, 181, 496-503.

19 S. Nikodemski, J. Tong and R. O'Hayre, Solid State Ionics, 2013, 253, 201-210.

20 J. Tong, D. Clark, L. Bernau, M. Sanders and R. O'Hayre, J. Mater. Chem., 2010, 20, 6333-6341.

21 W. G. Coors, A. Manerbino, D. Martinefski and S. Ricote, in Perovskite Mater. - Synth. Characterisation, Prop. Appl., InTech, 2016.

22 D. A. Medvedev, A. A. Murashkina and A. K. Demin, Rev. J. Chem., 2015, 5, 193-214.

23 P. Babilo and S. M. Haile, J. Am. Ceram. Soc., 2005, 88, 23622368. 
24 S. Ricote and N. Bonanos, Solid State Ionics, 2010, 181, 694700.

25 M. Biswas, H. An, S. M. Choi, J. W. Son, J. H. Lee, B. K. Kim, H. W. Lee and K. J. Yoon, Ceram. Int., 2016, 42, 10476-10481.

26 D. Han, S. Uemura, C. Hiraiwa, M. Majima and T. Uda, ChemSusChem, 2018, 16, 1-13.

27 Y. Guo, Y. Lin, R. Ran and Z. Shao, J. Power Sources, 2009, 193, 400-407.

28 D. Han, J. Iihara, S. Uemura, K. Kazumi, C. Hiraiwa, M. Majima and T. Uda, J. Mater. Chem. A, 2016, 4, 1060110608.

29 N. Nasani, D. Pukazhselvan, A. V. Kovalevsky, A. L. Shaula and D. P. Fagg, J. Power Sources, 2017, 339, 93-102.

30 E. Kim, Y. Yamazaki, S. M. Haile and H.-I. Yoo, Solid State Ionics, 2015, 275, 23-28.

31 D. Ciria, M. Ben Hassine, M. Jiménez-Melendo, A. Iakovleva, P. Haghi-Ashtiani, V. Aubin and G. Dezanneau, J. Power Sources, 2016, 321, 226-232.

32 J. Tong, D. Clark, L. Bernau, A. Subramaniyan and R. O'Hayre, Solid State Ionics, 2010, 181, 1486-1498.

33 Z. Liu, X. Wang, M. Liu and J. Liu, Int. J. Hydrogen Energy, 2018, 43, 13501-13511.

34 D. Yun, J. Kim, S. J. Kim, J. H. Lee, J. N. Kim, H. Yoon, J. Yu, M. Kwak, H. Yoon, Y. Cho and C. Y. Yoo, Energies, 2018, 11, 3083.

35 P. Babilo, T. Uda and S. M. Haile, J. Mater. Res., 2007, 22, 1322-1330.

36 M. Shirpour, B. Rahmati, W. Sigle, P. A. van Aken, R. Merkle and J. Maier, J. Phys. Chem. C, 2012, 116, 2453-2461.

37 Y. Huang, R. Merkle and J. Maier, Solid State Ionics, 2020, 347, 115256.

38 M. Chen, D. Chen, K. Wang and Q. Xu, J. Alloys Compd., 2019, 781, 857-865.

39 G. K. Williamson and W. H. Hall, Acta Metall., 1953, 1, 22-31.

40 J. E. Burke and D. Turnbull, Prog. Met. Phys., 1952, 3, 220292.

41 R. M. German, P. Suri and S. J. Park, J. Mater. Sci., 2009, 44, $1-39$.

42 O.-H. Kwon and G. L. Messing, J. Am. Ceram. Soc., 1990, 73, 275-281.

43 E. Jud, C. B. Huwiler and L. J. Gauckler, J. Ceram. Soc. Jpn, 2006, 114, 963-969.
44 V. Pavlovic, B. Stojanovic, L. Zivkovic, G. Brankovic and M. Ristic, Ferroelectrics, 1996, 186, 165-168.

45 S. B. C. Duval, P. Holtappels, U. F. Vogt, U. Stimming and T. Graule, Fuel Cells, 2009, 9, 613-621.

46 S. B. C. Duval, P. Holtappels, U. F. Vogt, E. Pomjakushina, K. Conder, U. Stimming and T. Graule, Solid State Ionics, 2007, 178, 1437-1441.

47 Y. Yamazaki, R. Hernandez-Sanchez and S. M. Haile, Chem. Mater., 2009, 21, 2755-2762.

48 D. Han, N. Hatada and T. Uda, J. Am. Ceram. Soc., 2016, 99, 3745-3753.

49 F. Iguchi, C.-T. Chen, H. Yugami and S. Kim, J. Mater. Chem., 2011, 21, 16517-16523.

50 F. Iguchi, N. Sata, T. Tsuri and H. Yugami, Solid State Ionics, 2007, 178, 691-695.

51 P. Babilo, PhD thesis, California Institute of Technology, 2007.

52 R. Sažinas, I. Sakaguchi, M. A. Einarsrud and T. Grande, Inorganics, 2018, 6, 14.

53 R. Sažinas, I. Sakaguchi, M. A. Einarsrud and T. Grande, AIP Adv., 2017, 7, 115024.

54 K. D. Kreuer, S. Adams, W. Munch, A. Fuchs, U. Klock and J. Maier, Solid State Ionics, 2001, 145, 295-306.

55 L. Malavasi, H. J. Kim and T. Proffen, J. Appl. Phys., 2009, 105, 123519.

56 Y. Huang, PhD thesis, University of Stuttgart, 2020.

57 D. Han, K. Shinoda, S. Tsukimoto, H. Takeuchi, C. Hiraiwa, M. Majima and T. Uda, J. Mater. Chem. A, 2014, 2, 1255212560.

58 D. Han, K. Goto, M. Majima and T. Uda, ChemSusChem, 2021, 14, 614-623.

59 Y. Yamazaki, R. Hernandez-Sanchez and S. M. Haile, J. Mater. Chem., 2010, 20, 8158-8166.

60 J. J. Lander, J. Am. Chem. Soc., 1951, 73, 2450-2452.

61 D. Han, Y. Otani, Y. Noda, T. Onishi, M. Majima and T. Uda, RSC Adv., 2016, 6, 19288-19297.

62 H. Shimada, T. Yamaguchi, H. Sumi, Y. Yamaguchi, K. Nomura and Y. Fujishiro, Ceram. Int., 2018, 44, 31343140 .

63 W. Deibert, M. E. Ivanova, Y. Huang, R. Merkle, J. Maier and W. A. Meulenberg, 2021 to be submitted. 